\title{
Myristoylated Alanine-Rich C-Kinase Substrate
}

National Cancer Institute

\section{Source}

National Cancer Institute. Myristoylated Alanine-Rich C-Kinase Substrate. NCI Thesaurus. Code C122755.

Myristoylated alanine-rich C-kinase substrate (332 aa, $\sim 32 \mathrm{kDa}$ ) is encoded by the human MARCKS gene. This protein plays a role in the crosslinking of actin filaments. 